\title{
Pemahaman Hadis Ali Mustafa Yaqub dan Kontribusinya Terhadap Pemikiran Hadis di Indonesia
}

(Ali Mustafa Yaqub's Understanding of Hadiths and his Contributions to the Thoughts of Hadiths in Indonesia)

\section{Muhammad Qomarullah}

STAI Bumi Silampari Lubuklinggau, Indonesia

ichalmarpolet@gmail.com

DOI: $10.29240 /$ alquds.v4i2.1862

Submitted: 2019-08-06 | Revised: 2020-08-18 | Accepted: 2020-10-05

\begin{abstract}
This is a qualitative study that delves into the hadith figure of the 20th century, Ali Mustafa Yaqub. This study aims to reveal Ali Mustafa Yaqub's understanding of hadiths according to his thoughts alongside his contributions to the thoughts of hadiths in the contemporary era. According to him, the study of hadiths in the current era must include Mustalah al-Hadith, Takhrij al-Hadith, Fiqh al-Hadith, and Difa 'an al-Hadith. According to him, the authenticity of hadiths can be known by comparing them with other hadiths from peers, in terms of time, from various narrators, and also from teachers or the works in hadith books. In so doing, the credibility of hadiths is known. Subsequently, his contributions to the thoughts of hadiths extend to introducing orientalist thinking and defending scholars, developing the method of understanding hadiths by establishing Darussunnah Islamic Boarding School, and writing various hadith thoughts that contain reconstructions of the understanding of hadiths in the form of either criticism or new thoughts about hadiths such as the meaning of bid'ah or hadiths in community debates related to law.
\end{abstract}

Keywords: the thoughts of hadiths, the orientalist, Difa 'an al-Hadits, the reconstruction of thoughts

Abstrak. Penelitian ini merupakan penelitian kualitatif yang mengkaji tokoh hadits abad 20 Ali Mustafa Yaqub.Penelitian ini bertujuan untuk mengungkap pemahaman Ali Mustafa Yaqub tentang pemahaman hadits dari pemikirannya dan kontribusinya terhadap pemikiran hadits di era kontemporer. Menurutnya, kajian hadits di era kekinian harus mencakup Mustalah al-Hadits, Takhrij al-Hadits, Fiqh al-Hadits, kemudian Difa 'an al-Hadits. Menurutnya, keaslian hadits dapat diketahui dengan membandingkan dengan hadits lain, baik dari teman, maupun waktu, dari berbagai perawi, maupun guru atau karya dalam sebuah kitab hadits, sehingga kredibilitas hadits tersebut dikenal. Adapun kontribusinya terhadap pemikiran hadits yaitu mengenalkan pemikiran orientalis dan membela ulama, kemudian mengembangkan metode pemahaman hadits dengan mendirikan Pondok Pesantren Darussunnah, menulis 
berbagai pemikiran hadits yang mengandung rekonstruksi ulang pemahaman terhadap hadits baik dalam bentuk kritik, atau pemikiran baru tentang hadits seperti makna bid'ah atau hadits dalam perdebatan masyarakat terkait hukum

Kata Kunci: Pemikiran Hadits, Orientalis, Difa 'an al-Hadits, rekonstruksi pemahaman

\section{Pendahuluan}

Ali Mustafa Yaqub termasuk salah seorang ulama hadis yang hidup di era abad 21 di Indonesia. Kajian tentang beliau banyak sekali, yang membahas tentang pemahaman hadis yang termaktub dalam karya-karya ilmiah berupa buku dan lainnya. ${ }^{1}$ Pengaruh pemikiran beliau pun sangat besar dalam mengkanter pemikir orientalis yang salah dalam memahami seluk-beluk hadis. ${ }^{2}$ Kajian pokok hadis yang beliau paparkan banyak sekali bersifat tematis untuk menetapkan hukum dari kontek kekinian, sehingga asas hukum sebagai jalan memanusiakan manusia itu dapat ditegakkan. ${ }^{3}$

Ali Mustafa Yaqub masuk dalam deretan tokoh yang relatif berpengaruh dalam kancah keilmuan di Indonesia, yang banyak menyumbangkan gagasan berilian dan merupakan pakar dalam bidang hadis karena produktifitasnya dalam kajian hadis. Terbukti beliau sudah didaulat sebagai guru besar dalam bidang hadis, kepakaran Ali Mustafa dalam bidang ini sangat diakui karena otoritas keilmuannya di bidang hadis mengenai kisi-kisi kehidupan, prilaku dan tindakan Rasulullah. ${ }^{4}$ Ia adalah pribadi yang ikhlas dan berhati baik, yang memaparkan sesuatu sesuai pengasaan ilmu hadisnya. ${ }^{5}$

Ali Mustafa Yaqub banyak melakukan akselerasi lebih jauh tentang pemahaman hadis dalam konteks ke-Indonesiaan. ${ }^{6}$ Dibalik itu, beliau sangat

${ }^{1}$ Dewi Anggraeni and Siti Suhartinah, "Toleransi Antar Umat Beragama Perspektif KH. Ali Mustafa Yaqub," Jurnal Studi Al-Qur'an 14, no. 1 (January 1, 2018): 59-77, doi:10.21009/JSQ.014.1.05.

${ }^{2}$ Ali Mustafa Yaqub, "Autentisitas Dan Otoritas Hadis Dalam Khazanah Keilmuan Ulama Muslim Dan Sarjana Barat," Tarjih: Jurnal Tarjih dan Pengembangan Pemikiran Islam 7, no. 1 (2004): 33-41.

${ }^{3}$ Ramadhan, "Metode Kritik Hadis Ali Mustafa Yaqub; Antara Teori Dan Aplikasi," accessed November 3, 2020, http://journal.tebuireng.ac.id/index.php/nabawi/article/view/5.

${ }^{4}$ Ramli Abdul Wahid, Sejarab Pengkajian Hadis Di Indonesia (Medan: IAIN Press, 2010), 35.

${ }^{5}$ Ali Yafie, Tabloid Jurnal Islam No. 70. Jakarta, 2-8 Dzulhijjah 1422 H/15-21 Februari 2002M dikutip dari halaman belakang buku Ali Mustafa Yaqub, Hadis-Hadis Bermasalah (Jakarta: Pustaka Firdaus, 2016). Lihat juga Ramli, Ibid.

${ }^{6}$ Banyak pemikiran hadis ke-Indonesiaan Ali Mustafa Yaqub ini asing di telinga masyarakat Indonesia, karena beliau sepertinya membenturkan budaya Indonesia dengan hadis Nabi. Lihat MISKI M. M, "Pemahaman Hadis Ali Mustafa Yaqub Studi Atas Fatwa Pengharaman Serban Dalam Konteks Indonesia," accessed November 3, 2020, doi:10.21043/riwayah.v2i1.1625. 
besar toleransinya terhadap umat beragama. ${ }^{7}$ Pemikiran beliaupun terbuka dengan konsep pemikiran barat dengan sebuah catatan, walaupun keilmuan beliau berasal dari timur tengah. ${ }^{8}$ Tapi beliau tidak meninggalkan historisitas hadis dan outentisitasnya dalam merefleksikan pesan kenabian.

Dari berbagai macam pemikiran Ali Mustafa Yaqub ini, penulis akan menelisik lebih dalam tentang beliau, kiprah keagamaan, karya-karya dan pemikiran hadisnya. Mudah-mudahan tulisan ini dapat menggambarkan potret seorang Ali Mustafa Yaqub serta pemikiran beliau dalam perspektif hadis nabi.

\section{Profil Ali Mustafa Yaqub}

\section{Riwayat Hidupnya}

Ali Mustafa Yaqub lahir di desa Kemiri, kecamatan Subah, Kabupaten Batang, Jawa Tengah, tanggal 2 Maret tahun 1952. Sejak kecil hingga dewasa Ali Mustafa tumbuh dalam lingkungan yang religius. Lingkungan yang penuh dengan nuansa keagamaan ini menginspirasi Ali Mustafa untukmenjadi seorang yang ahli agama di kemudian hari. ${ }^{10}$

Ayahnya bernama H. Yaqub (w. 1971) merupakan seorang muballig dan imam masjid di daerah Batang Jawa Tengah, serta mengajar di lembaga pendidikan yang dirikan bersama kakeknya Joyo Truno yang santrinya adalah masyarakat di sekitar rumahnya dengan kata lain sebagai kiayi kampung. ${ }^{11}$ Ibunya bernama Siti Chabibah (w. 2007H), ${ }^{12}$ merupakan seorang guru agama

7 Anggraeni and Suhartinah, "Toleransi Antar Umat Beragama Perspektif KH. Ali Mustafa Yaqub," 59-77.

8 Rohmansyah Rohmansyah, "Hadith Hermeneutic of Ali Mustafa Yaqub," KALAM 11, no. 1 (June 30, 2017): 187-214, doi:10.24042/klm.v11i1.1053.

9 Yaqub, "Autentisitas Dan Otoritas Hadis Dalam Khazanah Keilmuan Ulama Muslim Dan Sarjana Barat," 41.

${ }^{10}$ Ramli Abdul Wahid, Sejarah Pengkajian Hadis Di Indonesia, 36.

${ }^{11}$ Bentuk pengajaran yang dilakukan oleh ayah dan kakeknya berupa pengajian mingguan setiap malam senin dan malam kamis untuk bapak-bapak dan ibu-ibu kampung, sedangkan pembelajaran untuk anak-anak dilakukan dengan materi ilmu agama dan belajar bahasa Arab. Adapun Nama Joyo Truno didapatkan dari hasil wawancara Rizki Efendi pada 07 Desember 2008. Lihat Nasrullah Nurdin, "Prof. Dr. KH. Ali Mustafa Yaqub, MA. : Muhaddis Nusantara Bertaraf Internasional," Jurnal Lektur Keagamaan 14 (June 30, 2016): 198, doi:10.31291/jlk.v14i1.481.

${ }^{12}$ Pemakalah menemukan data mengenai nama ibu beliau yaitu "Hj. Habibah" yang data didapatkan dari istri beliau. Lihat Annisa Nurul Hasanah, "Mengenal K.H. Ali Mustafa Yaqub: Ahli Hadis Indonesia Abad ke-21 - Bincang Syariah," BincangSyariah | Portal Islam Rabmatan lil Alamin, July 16, 2018, https://bincangsyariah.com/khazanah/mengenal-k-h-alimustafa-yaqub-ahli-hadis-indonesia-abad-21/. Diposting 16 Juli 2018. Diakses 29 Oktober 
yang turut membantu mengajar ayahnya. ${ }^{13}$ Ali Mustafa Yaqub adalah anak keempat dari tujuh bersaudara yang dua saudara beliau sudah meninggal.Salah satu saudaranya ialah Dahlan Nuri Yaqub yang merupakan salah satu pengasuh di Pondok Pesantren Darussalam Batang Jawa Tengah yang didirikan bersama Ali Mustafa Yaqub tahun 1989. ${ }^{14}$

Ali Mustafa Yaqub memiliki seorang istri bernama Ulfa Uswatun Hasanah, merupakan murid beliau di Institut Ilmu al-Qur'an yang dinikahi pada pada tanggal 5 Mei 1990. ${ }^{15}$ Isteri Ali Mustafa Yaqub jugasebagai pendiridan pengasuh pondok pesantren Darussunnah International Institut for Hadith Sciancesyang didirikan Ali Mustafa Yaqub sejak tahun 1997 di Cengkareng. Ali Mustafa Yaqub memiliki seorang putra semata wayang bernama Ziaul Haramain yang mengajar di Darul Ulum New York, Amerika Serikat dan sekarang kembali ke pesantren Darussunnah melanjutkan perjuangan ayahnya. ${ }^{16}$

Beliau meninggal dunia pada hari Kamis 28 April 2016, Pukul 06.30 WIB dalam umur 64 tahun di Rumah sakit Hermina Ciputat Tanggerang akibat penyakit Gula atau Diabetes. Sebelum meninggal, tepatnya hari Rabu tanggal 27 April 2016, beliau sempat mengeluh masuk angin. Jenazah di semayamkan di Komplek Pesantren Darussunnah dan dikuburkan di belakang masjid Muniroh Salamah dalam lokasi Pondok Pesantren juga. ${ }^{17}$

\section{Perjalanan Menuntut Ilmu}

Ali Mustafa Yaqub menempuh pendidikan Sekolah Dasar (Sekolah Rakyat) tahun 1961-1966 di kampung halamannya.Tiap hari sehabis belajar di sekolah,beliau habiskan untuk menemani kawan yang menggembala kerbau di

2018. Diakses 29 Oktober 2018. Dalam makalah Nasrullah Nurdin bahwa nama ibu Ali Mustafa Yaqub Siti Habibah. Lihat juga Nasrullah Nurdin, "Prof, h. 199. Ada lagi yang mengatakan nama ibunya Siti Zulaikha. Lihat Dewi Angreini, "Toleransi, h. 62.

13 Ibukandung Ali Mustafa Yaqub menceritakan bahwa sewaktu bayi ada yang menceritakan bahwa Ali kecil akan menjadi Ulama besar saat sedang menggendongnya karena ada tanda-tandanya. Ibu Siti Chabibah meninggal dalam umur 88 tahun. Lihat AM. Waskito, KH. Ali Mustafa Yaqub: Menjaga Sunnah Mengawal Akidah (Jakarta: Pustaka al-Kautsar, 2016), 6061.

14 Data tersebut adalah hasil wawancara Ni'ma Diana Kholidah bersama Ali Mustafa Yaqub pada tanggal 22 Januari 2011. Lihat Ni'ma Diana Kholidah, "Kontribusi Ali Mustafa Yaqub Terhadap Kajian Hadis Kontemporer Di Indonesia," Skripsi” (UIN Syarif Hidayatullah, 2011), 11-12.

${ }^{15}$ Lihat Hasanah, "Mengenal K.H. Ali Mustafa Yaqub."

16 "Ali Mustafa Yaqub Pesan Makam 2 Tahun Sebelum Wafat - News Liputan6.Com," accessed November 3, 2020, https://www.liputan6.com/news/read/2494833/ali-mustafayaqub-pesan-makam-2-tahun-sebelum-wafat.

${ }^{17}$ Khairul Imam Ghozali, "Tangis Haru Ratusan Santri Antar Jenazah KH Ali Mustafa Yaqub Ke Pemakaman,” accessed November 3, 2020, https://news.detik.com/berita/d3198865/tangis-haru-ratusan-santri-antar-jenazah-kh-ali-mustafa-yaqub-ke-pemakaman. 
lereng-lereng bukit pesisir Utara Jawa Tengah. Kebiasaan ini kelak membentuk karakter (character building) dan sisi kepribadian Ali Mustafa Yaqub yang tegas, disiplin,kritis dan peduli antar sesama. Sejak kecil, Ali Mustafa Yaqub dan kakaknya dididik agama oleh kedua orangtuanya dan kakeknya serta diajarkan untuk belajar hidup sederhana dan tidak berfoya-foya serta hidup mandiri. ${ }^{18}$

Sekolah Menengah Pertama (SMP), Ayahnya lebih memilih mondokkanAli Mustafa Yaqub ke pesantren di Pesantren Seblak,Jombang, sampai tingkat Tsanawiyah tahun 1966-1969. ${ }^{19}$ Ali Mustafa Yaqub melanjutkan sekolah Aliyah (SMA) di Tebuireng Jombang yang tidak jauh dari Seblak tahun $1969-1972 .^{20}$

Ali Mustafa Yaqub melanjutkan kuliah Jenjang S-1 pada Program Studi Syariah Universitas Hasyim Asy'ari Jombang tahun 1972-1975, seta menekuni kitab-kitab kuning dibawah asuhan para guru-guru senior, sambil mengabdi selama 5 tahun sebagai guru di pesantrenTebuireng tahun 1972-1976. ${ }^{21}$

Setelah menyelesaikan kuliah di Uneversitas Wahid Hasyim, ia mengambil kembali jenjang S-1program beasiswa di Universitas King Saud, Riyad, Saudi Arabia dengan ijazah Licance (Lc) 1976-1980. Setelah lulus dari Universitas King Saud, Ali Mustafa Yaqub melanjutkan pendidikan ke jenjang Pasca Sarjana (S2) dengan spesialisasi tafsir dan hadis, di kampus yang sama dengan gelar Master of Art (MA) pada 1980-1985. ${ }^{22}$

${ }^{18}$ Lihat Nurdin, "Prof. Dr. KH. Ali Mustafa Yaqub, MA.," 198-99.; M, "Pemahaman Hadis Ali Mustafa Yaqub Studi Atas Fatwa Pengharaman Serban Dalam Konteks Indonesia," 18.; Ni'ma Diana Kholidah, "Kontribusi Ali Mustafa Yaqub Terhadap Kajian Hadis Kontemporer Di Indonesia," Skripsi," 11-12.

${ }^{19}$ Pondok Pesantren Seblak adalah Pondok Slafiyah Syafi'iyah Mahfuz Dwiek Karang Seblak, didirikan oleh KH Ma'shum bin Ali Jombang (1305H/1887M-1351H/1933H) yang bernama lengkap Muhammad Ma'shum bin Ali bin Abdul Jabbar al-Maksumambani saat umurnya 26 tahun. Pondok Pesantren ini berjarak $\pm 300 \mathrm{~m}$ dari pesantren Tebuireng. Beliau santri sekaligus menantu $\mathrm{KH}$. Hasyim Asy'ari yang menikahi $\mathrm{Hj}$. Khoiriyah Hasyim. Ia merupakan pengarang kitab "al-Amilah at-Tarf" dan Kitab "ad-Durus al-Falakiyah." Beliau wafat saat berumur 46 tahun. Pimpinan digantikan oleh KH Mahfudz Anwar menantu KH Ma'shum Ali yang menikahi putri pertamanya A’bidah Ma'shum. Lihat Arwin Juli Rahmadi Butar Butar, Mengenal Karya-Karya Ilmu Falak Nusantara: Transmisi, Anotasi Dan Biografi (Yogyakarta: LKiS, 2017), 84-87. Lihat Juga Muhammad Al-Fitra Haqiqi, 50 Ulama Agung Nusantara (Jombang: Darul Hikmah, 2009), h. 113-118 (Jombang: Darul Hikmah, 2009), 113-18.

${ }^{20}$ Lihat Ali Mustafa Yaqub, Hadis, h. 143. Ali Mustafa Yaqub, Sejarah, h. 240.Lihat juga Ramli Abdul Wahid, Sejarah, h. 36. Lihat Juga Ali Wafa, “ Kiai, h. 1-17.

${ }^{21}$ Lihat Ali Mustafa Yaqub, Hadis, h. 143; Ali Mustafa Yaqub, Sejarah, h. 240; Ramli Abdul Wahid, Sejarah, h. 36; Ali Wafa, "Kiai, h. 1-17; Nurdin, "Prof, h. 198-199; Miski, "Pemahaman, h. 18; Ni'ma Diana Cholidah, "Kontribusi, h. 11-12.

$$
{ }^{22} \text { Ibid. }
$$


Gelar S3 ia peroleh dari Universitas Nizamia, Hyderabad India dengan spesialisasi Hukum Islamtahun 2005-2008, ${ }^{23}$ dengan mempertahankan disertasi ujian promosi yang berjudul: "Kriteria Halal-Haram untuk Pangan, Obat Kosmetik dalam Pespektif al-Qur'an dan Hadis," diketuai tim penguji internasional dipimpin oleh Prof. Dr. M. Hasan Hitou, Guru Besar Fiqh Islam dan Usul Fiqh Universitas Kuwait yang juga Direktur Ilmu-Ilmu Islam Frankfurt Jerman, yang dilaksanakan hari Senin Malam, 30 Juni 2008 di Aula Masjid Istiqlal Jakarta. ${ }^{24}$

\section{Karir Akademik dan Dakwah}

Sebagai ulama yang cukup berpengaruh serta berdedikasi tinggi terhadap perkembangan Islam terutama kontribusinya dalam hadis dan ilmu hadis, maka pemakalah hanya merangkum sedikit dari rekam jejak karir beliau antara lain:

Karir Akademik Ali Mustafa Yaqub dengan menjadi dosen di berbagai kampus yaitu: Institut Ilmu al-Qur'an (IIQ) Jakarta (1985-2016); Perguruan Tinggi Ilmu al-Qur'an (PTIQ)(1986-2016); IAIN Syarif Hidayatullah Fakultas Ushuluddin Jakarta, yang sekarang berubah menjadi UIN Syarif Hidayatullah (1987-1988); Institut Agama Islam Shalahuddin Al-Ayyubi (INISA) Tambun Bekasi (1989-1990); Pendidikan kader ulama (PKU) MUI; Sekolah Tinggi Ilmu Dakwah (STDIA) Al- Hamidiyah Jakarta. ${ }^{25}$

Adapun dakwah dan organisasi yaitu: Pendiri pondok pesantren DarusalamDesaBatang Jawa Tengah (1989); Ketua umum PenghimpunanPelajar Indonesia (PPI) Riyad (1995-1997); Pengasuh Pondok Pesantren Al-Hamidiyah Depok (1995-1997); Ketua STIDA Al-Hamidiyah (1991-1997); Sekretaris Jenderal Pimpinan Pusat Ittihadul Muballighin (19901996); Ketua DewanPakar merangkap Ketua Departemen Luar Negeri DPP Ittihadul Muballighin (1996-2000); Guru Besar untuk ilmu hadis Institut Ilmu Al-Qur'an ( IIQ) Jakarta (1998-2016); Angota komisi Fatwa MUI pusat; Ketua Lembaga Pengkajian Hadits Indonesia (LePHI); Pengasuh Rubrik

${ }^{23}$ Lihat Istianah Istianah, "Kontribusi Ali Mustafa Yaqub (1952-2016) Dalam Dinamika Kajian Hadis Di Indonesia,” Riwayah 3, no. 1 (2017): 13, doi:10.21043/riwayah.v3i1.3442. Lihat juga Hartono, "Perkembangan Pemikiran Hadis Kontemporer Di Indonesia: Studi Atas Pemikiran Abdul Hakim Abdat Dan Ali Mustafa Yaqub" (Tesis, Sekolah Pascasarjana UIN Syarif Hidayatullah, 2009), 83-84.

${ }^{24}$ Adapun Para anggota penguji: Prof. Dr. Taufiq Ramadhan al-Buthi (Guru Besar dan Ketua Jurusan Fiqh dan Ushul Fiqh Universitas Damaskus, Syria), Prof. Dr. Mohammed Khaja Sharief M. Shahabuddin (Guru Besar dan Ketua Jurusan HadisUniversitas Nizamia, Hyderabad, India) dan Prof. Dr. M. Saifullah Mohammed Afsafullah (Guru Besar dan Ketua Jurusan Sastra Arab Universitas Nizamia). Lihat. https://www2.kemenag.go.id/berita/79915/imam-besarmasjid-istiqlal-diuji-ulama-manca-negara. Diakses 30 Oktober 2018.

${ }^{25}$ Jamal Ma’mur Asmani, Mereguk Kearifan Para Kiai (Jakarta: Gramedia, 2018), 211-13. Lihat Istianah, "Kontribusi Ali Mustafa Yaqub (1952-2016) Dalam Dinamika Kajian Hadis Di Indonesia," 13-14. Lihat Dewi Angreini, “Toleransi, h. 63-65. 
Hadits/Mimbar Majalah Amanah Jakarta; Pendiri dan Pengasuh Pondok Pesantren Luhur Ilmu Hadis Darussunnah (1997-2016); Imam Besar Masjid Istiqlal Jakarta (2005-2016). ${ }^{26}$

\section{Guru-Gurunya}

Adapun guru-guru Ali Mustaf Yaqub sangaat banyak sekali yang ikut andil dalam membentuk keilmuan, pemikiran dan karekteritik serta seang beliau dalam masa hidup beliau, terutama kedua orang tua dan kakeknya. Pemakalah hanya menggambarkan sedikit dari gurunya yang berpengaruh antara lain:

K.H. Idris Kamali, bernama lengkap Idris bin Kamali bin abdul Jalil asySyarbuni. Beliau menguasai Bahasa Arab, hadis, ilmu Falak, qira'ah, Fiqih, Tasawwuf dan pernah dipercayakan menjadi Pengajar di masjid al-Haram Mekkah tahun 1973-1981. Sebelum Kiai Idris Kamali Pondok Pesantren Jombang beliau belajar di Pondok Pesantren APIK Kaliwungu Kendal. Akhirnya beliau dijadikan menantu oleh KH. Hasyim Asy'ari dengan menikahi anaknya Nyai Azza. ${ }^{27}$ Ali Mustafa Yaqub belajar dengan beliau kitab kuning dengan metode Sorogan yaitu membacakan kitab didepan guru.Ali Mustafa Yaqub menganggap beliau sangat berpengaruh bagi Ali Mustafa Yaqub, ilmu dasar dari pemahaman terhadap Alquran dan hadis banyak didapat dari sang kiai. Hidup sang Kiai hanya untuk mengayomi dan melayani santri karena kecintaannya kepada santri, kenang Ali Mustafa Yaqub. ${ }^{28}$

Kemudian, K.H. Syansuri Badawi, yang lahir di Cirebon pada tahun 1918, beliau adalah salah satu murid langsung dari KH. Hasyim Asy'ari yang juga ahli hadis yang bersanad. Beliau pernah belajar di Pesantren Solo dan akhirnya menetap di Pesantren Tebuireng untuk belajar. ${ }^{29}$ Ali Mustafa Yaqub belajar dengan beliau semasa mondok terutama pelajaran ilmu hadis dan hadis.

${ }^{26}$ Lihat Miski, "Pemahaman, h.18-19.Lihat Rohmansyah, "Hadith, 192-193. Lihat juga Yogi Sulaeman, “Analisis Wacana Kritis 'Dai Komersial' Dalam Buku Setan Berkalung Surban Karya Prof. Dr. KH. Ali Mustafa Yaqub, MA” (Skripsi, UIN Syarif Hidayatullah Fak. Dakwah dan Komunikasi, 2015), 43-44.

${ }^{27}$ Kiai Idris Kamali sempat tinggal di Mekkah dan mengajarkan kitab Sabih al-Bukhari dan Ibya' 'Ulum ad-Din ketika menetap disana tahun 1973-1981. Lihat Fathurrahman Karyadi, Tokoh Besar Dibalik Layar: Biografi Almarbum KH. Idris Kamali (Jombang: Pustaka Tebuireng, 2010), 128. Lihat juga Ali Wafa, "Manhaj Asy-Syaikh 'Ali Mustafa Yaqub Fi Fahm al-Ahya anNabawiyah” (Skripsi, UIN Syarif Hidayatullah Fak. Dirasat Islamiyah, 2014), 6-8.

${ }^{28}$ Ibid.

${ }^{29}$ Lihat Cholidi Ibhar, Mengais Keteladanan Dari Kiai Syansuri Badawi (Jombang: Pustaka Tebuireng, 2017), 1-6. Lihat juga Ali Wafa, "Manhaj Asy-Syaikh 'Ali Mustafa Yaqub Fi Fahm al-Ahya an-Nabawiyah," 7. 
KH. Syansuri terkenal sangat tegas dan lantang menyuarakan kebenaran terutama tentang hadis dan fiqhi. ${ }^{30}$

Banyak lagi guru-guru beliau yang lain seperti $\mathrm{KH}$. Adlan Ali, $\mathrm{KH}$ Shobari dan lainnya, semua pembelajaran yang ia dapatkan merupakan kaiian kitab yang berkaitan dengan Bahasa Arab, Ilmu Qira'ah, Alquran, hadis, hukum Islam, Adab dan Tasawwuf yang biasanya disebut pondok pesantren kitab kuning. ${ }^{31}$ Para Kiai inipun termasuk ulama yang produktif dalam menulis kitab di Pondok Pesantren Jombang dalam berbagai disiplin ilmu yang kemudian melahirkan banyak tokoh-tokoh besar di Indonesia yang pengaruhnya sampai ke manca negara. ${ }^{32}$

Selain itu, untuk di luar negeri, guru beliau yang paling berkesan ialah Prof. Dr. Mustafa A'zami di Riyad yang Ali Mustafa Yaqub sempat menerjemahkan karyanya yang berjudul:'Studies In Early Hadith Literature'yang diterjemahkan oleh Ali Musthafa Yaqub dengan judul 'Hadis Nabawi danSejarah Kodifikasinya'. Kitab ini merupakan penjelasan transpormasi dantraslitrasi hadis serta 'bantahan' terhadap pendapat orientalis Ignaz Goldziher dan Joseph Schacht yang menganggap jalur sanad hadis merupakan projecting back yang sebenarnya dibuat-buat dan dinisbatkan ke Nabi Muhammad. ${ }^{33}$ Selain itu, Prof. Dr. Muhammad Hassan Hitou dari India, Prof. Dr. Wahbah az-Zuhaili dari Suriah, Syaikh Abdul Aziz bin Abdullah bin Baz dari Riyad yang dikenal Ali Mustafa Yaqub saat di masa kuliah di Madinah ataupun di India. ${ }^{34}$

\section{Karya-karyanya}

Ada sejumlah buku Ali Mustafa Yaqub baik buku yang ditulis sendiri, karya terjemahan atau karya suntingan di antaranya adalah :Nasehat Nabi Kepada Pembaca dan Penghafal alquran (1990);Imam al-Bukharidan Metodologi Kritik dalam Ilmu Hadis (1991); Kritik Hadis (1995); Sejarah dan Metode Dakwah Nabi (1997); Peran Ilmu Hadis dalam Pembinaan Hukum Islam (1999); Kerukunan Umat Islam dalam Perspektif alquran dan al-Hadis (2000); Islam Masa Kini (2001); Fatwa-fatwa Kontemporer (2002); M. M. Azami Pembela Eksistensi Hadis, Pengajian Ramadhan Kyai Duladi (2003); Hadis-hadis Bermasalah (2003);dan Hadis-hadis Palsu Seputar

${ }^{30} \mathrm{KH}$ Syansuri Badawi sempat menjadi anggota DPR 1987 dan 1992 yang sangat menentang sekali pemimpin wanita. Lihat Muhammad Koderi, Bolebkah Wanita Menjadi Imam Negara (Jakarta: Gema Insani Press, 1999), 72-73.

${ }^{31}$ Lihat Jamal Ma'mur Asmani, Mereguk Kearifan Para Kiai, 211-12. Lihat Juga Ali Mustafa Yaqub, Kalau Istiqamah Enggak Bakal Takut Enggak Bakal Sedih (Jakarta: Naora, 2016), 191-92.

${ }^{32}$ Lihat Arwin Juli Rahmadi Butar Butar, Mengenal, h. 84-86.

${ }^{33}$ Lihat Ramli Abdul Wahid, Sejarah, h. 36-38. Lihat juga Ahmad Isnaeni, "Historitas Hadis Dalam Kacamata M. Mustafa Azami," Epistemé: Jurnal Pengembangan Ilmu Keislaman 9, no. 2 (December 10, 2014): 223-45, doi:10.21274/epis.2014.9.2.233-248.

${ }^{34}$ Lihat AM. Waskito, KH, h. 66-68 
Ramadhan (2003); Nikah Beda Agama dalam Perspektif Al-Qur'an ddan Hadits (2005); Imam Perempuan (2006); Fatwa Imam Besar Masjid Istiqlal (2007); Ada Bawal Kok Pilih Tiram (2008); Toleransi Antar Umat Beragama (2008); Islam di Amerika (2009); Kriteria Halal-Haram untuk. Pangan, Obat, dan Kosmetik; Menurut Al-Qur'an dan Hadits (2009); Waspadai Provokator Haji (2009); Islam, Between War and Peace (2009); Kidung Bilik Pesantren (2009);Kiblat antara Bangunan dan Arah Ka'bah (2010); 25 menit Bersama Obama (2010); Kiblat Menurut Al-Qur'an dan Hadits: Kritik atas Fatwa MUI No. 5/2010 (2011); Ramadhan bersama Ali Mustafa Yaqub (2011); Cerita dari Maroko (2012); makan Tak Pernah Kenyang (2012); Ijtihad, Terorisme, dan Libralisme (2012); Dalil Al-Hisab (2012); Panduan Amar Maruf Nabi Munkar (2012); Isbat Ramadhan, Syawal, dan Zulbijab Menurut AlQur'an dan Sunnah (2013); Menghafal Al-Qur'an di Amerika Serikat (2014); Cara Benar memahami Hadits (2014); Setan Berkalung Sorban (2014); Titik Temu Wababi NU (2015); Islam is Not Only for Muslim (2016); Teror di Tanah Suci (2016); Kalau Istiqamah Enggak. Bakal Takut Enggak. Bakal Sedih (2016). ${ }^{35}$

Karya-karya dalam bentuk terjemahanatau Bahasa Arab Ingris, suntingan buku adalah sebagai berikut: Memabami Hakekat Hukum Islam, alih bahasa dari Ali Bayuni (1986); bHadis Nabi dan Sejarah Kodifikasinya, karya M M. 'Azami (1994);bBimbingan Islam untuk Pribadi dan Masyarakat, alih bahasa dari Muhammad Jamil Zainu (1997); Aqidah Imam Empat: Abu Hanifah, Malik, Syafi i, dan Ahmad, alih bahasa dari Abdurrahman al-Khumayis (2001); Kemusyrikan Menurut Madzhab Syafi'i, alih bahasa dari Abdurrahman al-Khumayis (2001). ${ }^{36}$

Kata pengantar: Imam Jalal al-Din al-Suyuthi, Musnad Fatimah al-Zabra, alih bahasa Abdulrasyid Shiddiq(1997); Imam Nawawi, Dasar-dasar Ilmu Hadis, alih bahsa Syarif Hademasya (2001); Syeikh Ahmad Surkati, Hadis-hadis Lemah dan Palsu (2001); Muhammad Mushtafa al-Sibai, Hikmah dan Falsafah Puasa, alih bahasa Ahmad Husnul Hakim (2001); Usman Sya'roni, Otentisitas Hadis Menurut Abli Hadis dan Kaum Sufi (2002); Muhammad Nashir ad-Din al-Albani, Sifat Shalat Nabi (2002); Syeikh Ismail al-Anhari, Otentisitas Hadis Shalat Tarawih 20 Rekaat, sanggahan terhadap al-Albani, alih bahasa Mahfud Hidayat Lukman (2003). ${ }^{37}$

\section{Kontribusi Pemikiran Ali Mustafa Yaqub Terhadap Hadis}

\section{Diskripsi Pemikiran Hadisnya}

${ }^{35}$ Lihat AM. Waskito, KH., h. 42-45. Lihat juga Ramli Abdul Wahid, Sejarah, h. 37.

${ }^{36}$ Lihat AM. Waskito, KH., h. 42-45.

${ }^{37}$ Lihat Ali Mustafa Yaqub, Kalau, h. 192. Lihat AM. Waskito, KH., h. 42-45. Lihat juga Ali Wafa, "Manhaj, h. 19-24. 
Pemakala mencoba untuk mengkostruksikan pemikiran Ali Mustafa Yaqub secara mengeluruh dan kongkrit. Sebab, Ali Mustafa Yaqub termasuk ulama hadis yang cukup memberikan gambaran yang utuh terhadap ilmu hadis dan pemahaman hadis. Tapi, dalam kajian hadis yang begitu sangat luas dan mendalam selalu menyisakan ruang kosong yang harus dibahas sebagaimana pendapat Prof. Dr. H Ramli Abdul Wahid, MA., dalam buku yang berjudul 'Sejarah Pengkajian Hadis di Indonesia,' tapi, karya-karya Ali Mustafa Yaqub cukup menambah gairah dalam kajian hadis. ${ }^{38}$

Menurut Ali Mustafa Yaqub, studi hadis kontemporer harus komperehensif terdiri atas empat komponen. Pertama, Mustalah alHadis; Kedua, Takhrij al-Hadis pada studi Sanad; Ketiga, Figh al-Hadis yang merupakan metode untuk memahami hadis; dan keempat, Difa' 'an al-Hadis yang beguna untuk mempertahankan eksistensi hadis dari pihak orientalis dan pengingkar. Masing-masing dari empat komponen ini memiliki wilayah penelitian sendiri, kendati saling berkaitan. 39

Menurut Ali Mustafa Yaqub, apabila metode pengajaran ilmu hadis tersebut dapat diterapkan, maka pada masa mendatang ia mengharapkan akan lahir para ahli hadis yang tidak hanya mampu menyeleksi otentisitas dan kredibilitas sebuah hadis, tetapi juga mampu mempertahankan eksistensi hadis dan memahami hadis dengan pemahaman yang benar. Pemikiran Ali Mustafa Yaqub tersebut tidak hanya sekadar wacana, tapi telah ia terapkan di dalam kurikulum pesantren Darussunnah yang didirikannya. Dengan harapan para alumni Darussunnah menjadi aset berharga ulama hadis di Indonesia yang dapat ikut andil dalam mengajarkan hadis dengan pemahaman yang benar. ${ }^{40}$

Melihat berdirinya Pesantren Darussunah yang oleh Ali Mustafa Yaqub, menciptakan kurikulum pembelajaran hadis berkaitan denganTakbrij al-Hadis dan Naqd al-Hadis meliputi: (1) aspek kajian hadis yang langsung dari kitab induknya al-Kutub as-Sittah sampai selesai selama empat tahun dengan metode muzakarah dan mubadarab; ${ }^{41}$ (2) aspek kajian 'ulum al-Hadis yang ilmu musthalah

${ }^{38}$ Lihat juga Ramli Abdul Wahid, Sejarah, h. 40.

${ }^{39}$ Lihat Ali Wafa, “ Kiai, h. 11-13.

${ }^{40}$ Ibid.

${ }^{41}$ Mudzakarah adalah sistem belajar dengan metode membaca, memahami, dan mendiskusikan hadis-hadis yang akan dikaji setelah subuh bersama guru. Mudzakarah ini dilakukan setelah shalat Isya. Muhadharah adalah metode bandongan di mana guru menerangkan dan mahasantri mendengarkan serta memahami. Diterapkan pula di sini sistem sorogan, yaitu santri membaca kitab, Kiai atau Ustadz menyimak, mengoreksi dan Kiai menanyainya. Lihat Mujamil Qomar, Pesantren: Dari Transformasi Metodologi Menuju Demokratisasi Institusi (Jakarta: Penerbit Erlangga, 2010), 142-44. Lihat juga Ayung Darun Setiadi, Pendidikan Pesantren," Dalam Buku Ilmu \& Aplikasi Pendidikan (Bandung: PT. Imperial Bhakti Utama, 2007), 437. Lihat juga 
al-Hadis dijadikan sebagai landasan teori bagi pelajar hadis dalam menentukan kualitas hadis, dan mengamalkannya; (3) aspek kajian berbasis takbrij al-Hadis, analisis implementatif dalam melacak dan menelusuri hadis, membahas rawirawi dalam sanad, kemudian menyeleksi dan menghukumi kualitas hadisnya; (4) aspek kajian berbasis naqd al-Hadis (kritik hadis) yang diajarkan metode kritik hadis para sarjana muslim sebagai counter terhadap metode kritik hadis orientalis dari kajian Timur dan Barat; (5) pembekalan ilmu yang berbasis pemahaman hadis (Turuq fabm al-Hadis) dengan buku panduan at-Turuq al-Sabihah fi Fahm asSunnah an-Nabawiyyah karya Ali Mustafa Yaqub, ${ }^{42}$ sebagai upaya membedung pemahaman hadis yang sempit, kaku dan radikal, dengan tambahan belajar fiqih, ushul fiqh, bahasa Arab-Inggris dan materi-materi penunjang lainnya. ${ }^{43}$

Adapunjasa besar Ali Mustafa Yaqub dalam pemikiran hadis di Indonesia berupa: pertama, kritikan tajamnya terhadap orientalis Barat Ignaz Goldziher dan Joseph Schacht tentang studi hadis lewat pemikiran gurunya Mustafa Azami di Indonesia. ${ }^{44}$ Kedua, menghilangkan dikotomisasi ahli hadis dan ahli fiqh, sebab tiga imam madzhab lainnya adalah pakar hadis dan fikih sekaligus. ${ }^{45}$ Ketiga, mengenalkan metode Figh al-Hadis (pemahaman hadis)yang dituangkan dalam kitab yang berjudul at-Turuq as-Sabibah fi Fabm as-Sunnah anNabawiyah'yang diterjemahkan dengan judul 'Cara Benar Memahami Hadis'sebagai teknik untuk mengetahui hadis secara utuh agar tidak salah kaprah dalam memaknai hadis. ${ }^{46}$ keempat, mengkritisi tradisi-tradis masyarakat Indonesia yang tidak sesuai dengan Alqur'an dan hadis Nabi. ${ }^{47}$ Kelima, menggambarkan bahwa Islam rahmat sekalian alam yang bisa hidup berdampingan satu dan lainnya. ${ }^{48}$

George A. Makdisi, Cita Humanisme Islam, Terj. A. Syamsu Rizal \& Nur Hidayah (Jakarta: Serambi, 2005), 236.

${ }^{42}$ Kitab tersebut sudah dikonversi menjadi aplikasi yang mudah dibuka di computer serta mudah di-download dari internet berupa file e-book. Untuk petunjuk aplikasi lihat http://alumni.darussunnah.id/unduh/file/shamela-e-books/thuruq-sahihah-fi-fahmissunnah.

Diakses 01 November 2018.

${ }^{43}$ Lihat Ali Wafa, " Kiai, h. 11-13.

${ }^{44}$ Lihat Ali Mustafa Yaqub, Kritik Hadis, (Jakarta: Pustaka Firdaus, 2015), h. 7-38.

Lihat juga Ramli Abdul Wahid, Sejarah, h. 42-44. Lihat juga Ali Wafa, “ Kiai, h. 15-16.

${ }^{45}$ Lihat Ali Mustafa Yaqub, Peran Ilmu Hadis Dalam Pembinaan Hukum Islam (Jakarta: Pustaka Firdaus, 1999), 8. Secara ontologi Alquran, hadis, fiqhi merupakan satu bagian ilmu yang tak terpisahkan sebagaimana pendapat al-Farabi dan Ibnu khaldun. Lihat Mulyadi Kartanegara, Integrasi Ilmu: Sebuah Rekonstruksi Holistik (Jakarta: , 2005), h. 215-216. (Jakarta: Arasy Mizan, 2005), 215-16.

46 Ali Mustafa Yaqub, At-Turuq as-Sabihah Fi Fahm as-Sunnah an-Nabawiyyah (Jakarta: Maktabah Darus-Sunnah, 2016), 13. Lihat juga Ali Wafa, "Kiai, h. 15-16.

${ }^{47}$ Seperti karyanya tentang Setan Berkalung Sorban, Haji Pengabdi Setan sebagai ungkapan dari nafsu seseorang yang mengikuti kesesatan jalan Iblis, sebab haji wajibnya hanya sekali dan 
Otentisitas hadis menurut Ali Mustafa Yaqub dapat dianalisa dengan 'metode perbandingan', untuk mengidentifikasi sebuah hadis, sehingga dapat diketahui bahwa hadis tersebut kredibel (sigah) atau tidak. Pertama, memperbandingkan hadis-hadis yang diriwayatkan oleh sejumlah sahabat Nabi. Kedua, Memperbandingkan hadis yang diriwayatkan oleh seorang periwayat pada masa yang berlainan. Ketiga, membandingkan hadis-hadis yang diriwayatkan oleh periwayat-periwayat yang berasaldari seorang guru hadis.Keempat, membandingkan hadis yang diajarkan oleh seorang guru dengan guru-guru yang lain. Kelima, membandingkan antara hadis-hadis yang tertulis didalam buku dengan yang tertulis dalam buku yang lain atau dengan hafalan hadis.Keenam, Memperbandingkan hadis dengan ayat-ayat al-Qur'an. ${ }^{49}$

Menurut Ali Mustafa Yaqub, ketika mendapati teks hadis yang otentik berkaitan dengan masalah gaib (umur al-gaibiyah) dan ibadah murni (al-Tbadah alMahdhah), perkara gaibpun yang bukan yang relatif (nisbi), tapi yang mutlak (baqiqab), maka harus dipahami sebagaimana mestinya atau secara tekstual, tanpa boleh menafsirkan atau mengotak-atik. ${ }^{50}$ Bilamana hadis tidak dapat dipahami secara tekstual maka dapat dipahami secara kontekstual dengan syarat menafsirkannya dengan Alquran dan sunnah dulu sebelum meninterpretasinya, ${ }^{51}$ denganmelihat faktor; sebab turunnya (asbab al-wurud), lokalitas temporal (al-makan wa az-zaman), aspek kausalitas (illah al-kalam), serta sosiokultural (taqlid) masyarakat. ${ }^{52}$ Beliau berpendapat, bahwa hadis dipahami secara kontekstual dilakukan sebagai kearifan lokal, karena tradisi budaya setiap masyarakat Arab dan Indonesia itu berbeda. ${ }^{53}$

\section{Contoh Pemikiran Hadis}

a. Setan berkalung Sorban

banyak yang naik haji hanya ingin dianggap ahli ibadah, padahal sebaiknya uang itu bagusnya untuk hal lain yang lebih bermanfaat seperti membantu fakir miskin. Lihat AM. Waskito, KH.H. 46-50.

${ }^{48}$ Lihat Ali Mustafa Yaqub, Toleransi Antar Umat Beragama (Jakarta: Penerbit Pustaka Firdaus, 2008), 11-13. Lihat juga Ali Mustafa Yaqub, Kerukunan Umat Perspektif Al-Quran Dan Hadis (Jakarta: Penerbit Pustaka Firdaus, 2008), 28-69.

${ }^{49}$ Muhammad Azani, "Kritik Hadis Indonesia: Studi Pemikiran Ali Musthafa Yaqub," Jurnal Studi Ilmu-Ilmu Al-Qur'an dan Hadis, ISSN: 1411-6855(Vol. 8, No. 2, Juli 2007), h. 351-353.

${ }^{50}$ Lihat Ali Mustafa Yaqub, Islam Masa Kini (Jakarta: Pustaka Firdaus, 2006), 21. Lihat juga Ali Mustafa Yaqub, Fatwa-Fatwa Imam Besar Masjid Istiqlal (Jakarta: , 2008), h (Jakarta: Pustaka Firdaus, 2008), 28. Lihat juga Ni’ma Diana Kholidah, “Kontribusi, h. 48-50.

${ }^{51}$ Lihat Ali Mustafa Yaqub, Islam, h. 22.

${ }^{52}$ Lihat Ali Mustafa Yaqub, Haji Pengabdi Setan (Jakarta: Pustaka Firdaus, 2006), 15257. Lihat juga Ni'ma Diana Kholidah, "Kontribusi, h. 52-59.

${ }^{53}$ Lihat Ali Mustafa Yaqub, Haji, h. 157. Lihat Jamal Ma'mur Asmani, Mereguk, h. 215217. 
Tema atau topik adalah sebuah gambaran umum dari teks, dapat juga dikatakan sebuah gagasan inti atau ringkasan utama sebuah teks. Topik tulisan ini adalah tentang muamalah. Gagasan intinya adalah mengkritik dai yang hanya bermodal surban tetapi berdakwah tidak berdasarkan niat karena Allah swt. melainkan mengikuti hawa nafsu dan kehendak setan. ${ }^{54}$ Ali Mustafa Yaqub menuliskanhadis al-Bukhari yang berbunyi:

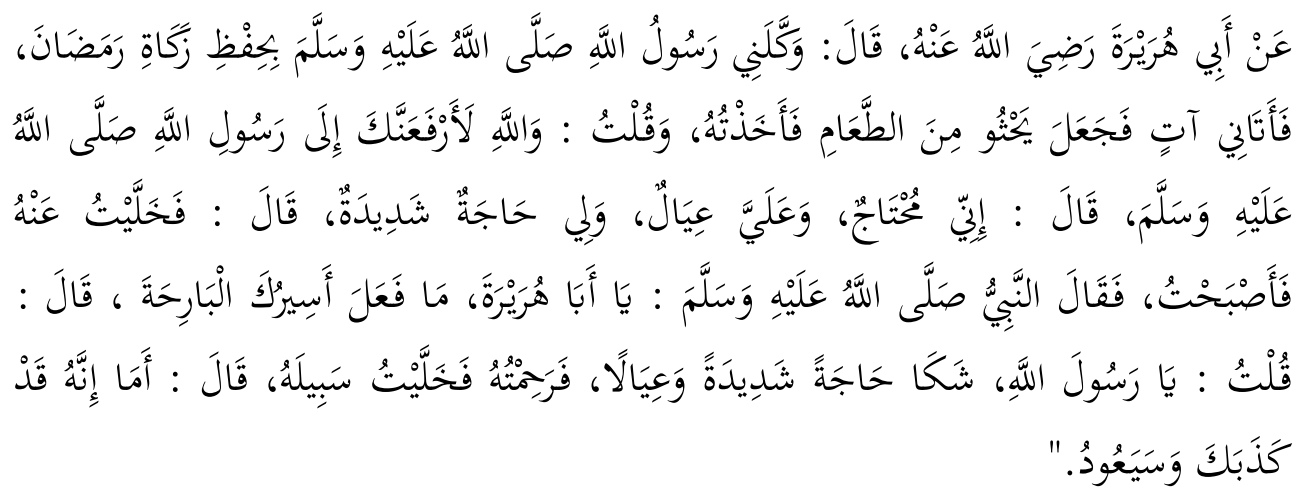

"Abu Hurairah ra. Bercerita: Suatu hari Rasulullah saw. menugaskan saya untuk menjaga harta rakat pada bulan Ramadhan. Tiba-tiba datanglab seseorang melihat-libat makanan dan langsung mengambilnya. Dia lalu saya tangkap, dan saya katakan: "Kamu akan saya laporkan kepada Rasul saw." orang itu menjawab: "Saya orang yang sudah berkeluarga dan sangat membutubkan makanan tersebut untuk keluarga saya." Mendengar itu saya pun melepaskannya. Ketika pagi tiba Rasul saw. bertanya: "Wabai Abu Hurairah apa yang kamu lakukan pada orang yang kamu tangkap tadi malam?” Saya menjawab: "Wabai Rasulullah, orang itu mengadukan kesusahan keluarganya, dan dia memohon barta rakat saat itu juga, lalu saya bebaskan." Rasul saw. bersabda: Dia telab mengelabuimu, dan nanti malam ia akan datang lagi. ${ }^{, 55}$

Tujuannya yang dimaksud Ali Mustafa yaqub adalah untuk mengajak agar membaca hadis Rasul saw. juga agar memberi penguatan pada pesannya. Inti dari tulisan ini berada dalam akhir cerita tersebut, sebagaimana perkataan Ali Mustafa Yaqub yang berbunyi:

'Dari Hadis ini, ada pelajaran menarik. Pertama, bahwa setan dapat menjelma menjadi manusia. Kedua, dalam rangka mengecoh dan mencari korban, setan dapat

\footnotetext{
54 Wawancara Yogi mengenai maksud hadis bersama Ali Mustafa Yaqub 18 Mei 2015 di Kediamannya. Lihat Yogi Sulaeman, "Analisis, h. 49.

${ }^{55}$ Lihat Ali Mustafa Yaqub,Setan, h. 92
} 

menjelma menjadi seorang ustaz atau ustazah dengan segala atribut dan nasehat-
nasehatnya."56

Menurut Ali Mustafa Yaqub, dalam berdakwah itu ada "Kode Etik Dakwah" yang harus dijaga untuk pegangan bagi para dai sebelum terjun ke lapangan, sebagaimana keputusan Musyawarah Nasional Ittihadul Muballighin, Organisasi para mubalig yang dipimpin oleh KH. Syukron Ma mun tahun 1996 yang beliau sebgai sekretaris. ${ }^{57}$ Inti dari tulisan ini berada dalam: "Salah satu keputusan penting yang diambil dalam Munas itu adalah merumuskan Kode Etik Dakwah. ${ }^{58}$ Keputusan ini diambil karena pada waktu itu mulai muncul dai Walakedu (jual Agama kejar duit). ${ }^{59}$

Tujuan dakwah menurut Ali Mustafa Yaqub adalah untuk: (1) menyeruh umat manusia hanya menyembah kepada Allah; (2) menyampaikan ajaran Allah; (3) memberikan bimbingan kepada umat manusia; (4) memberikan tauladan yang baik; (5) memperingatkan umat tentang kehidupan akhirat; (6) mengubah orientasi duniawi menjadi orientasi ukhrawi. ${ }^{60}$

Tulisan ini ditutup dengan memberikan sebuah peringatan kepada kita agar berhati-hati terhadap segala macam bentuk rayuan setan yang ada di dunia ini. Cerita ini berlangsung sampai tiga kali berulang-ulang dan pada hari ketiga Rasul saw. memberitahukannya bahwa ia adalah setan. Kesimpulan dari tulisan ini menjelaskan bahwa meskipun seseorang itu menggunakan surban dan menjadi dai, jika dakwahnya tidak berlandaskan ikhlas karena Allah, maka sama saja dakwahnya itu mengikuti rayuan setan dan hawa nafsunya. ${ }^{61}$

b. Hadis-Hadis Bermasalah

Berkenaan dengan salat Tasbih yang diperdebatkan, bahkan dianggap palsu. Ada dua permasalahan yang Ali Mustafa Yaqub menjadikan 'salat Tasbih' menjadi salah satu materi dalam bukunya. Pertama, sikap tidak penting pengetahuan tentang hadis berkaitan dengan hadis palsu atau tidak, dengan tetap menjalankan tuntunan salat Tasbih. Kedua, anggapan bahwa hadis tentang

${ }^{56}$ Ibid.

57 Lihat Mohammad Rofiq, "Etika Dakwah: Menyikapi Fenomena Da'i Bertarif," MIYAH : Jurnal Studi Islam 11, no. 2 (February 25, 2017): 83.

${ }^{58}$ Ada tujuh "Kode Etik Dakwah" dalam rumusan Musyawarah Ittihadul Muballigin 1996: 1). Tidak memisahkan antara Perbuatan dan Ucapan; 2). Tidak toleransi (bernegosiasi) dengan agama lain; 3). Tidak mencerca sembahyangan agama lain; 4). Tidak melakukan diskriminasi; 5). Tidak memungut imbalan; 6). Tidak mengawani pelaku maksiat; 7). Tidak menyampaikan hal-hal yang tidak diketahui.

${ }^{59}$ Lihat Ali Mustafa Yaqub,Setan, h. 105.

${ }^{60}$ Lihat Ali Mustafa Yaqub, Sejarah Metode Dakwah Nabi (Jakarta: Pustaka Firdaus, 2003), h. 155 (Jakarta: Pustaka Firdaus, 2003), 155. Lihat juga Rizki Efendi, "Pemikiran, h. 54-55.

${ }^{61}$ Lihat Yogi Sulaeman, "Analisis, h. 50-51. 
salat Tasbih itu palsu, sehingga tidak perlu menjalankannya. ${ }^{62}$ Ali Mustafa Yaqub mengutip hadis $\mathrm{Ab}-\mathrm{D} \pm$ ud dari Nabi kepada pamannya 'Abb \pm s, yang disampaikan lagi ke 'Abdull $\pm \mathrm{h}$ bin 'Abb \pm s dan lainnya yang berbunyi:

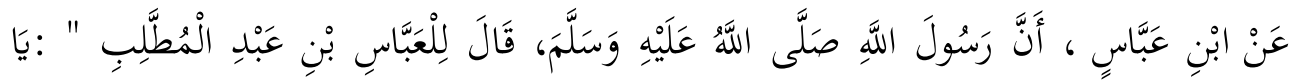

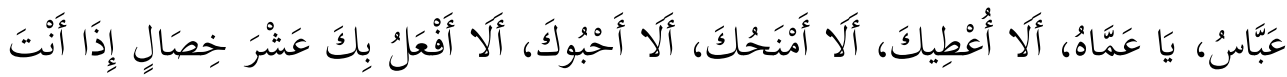

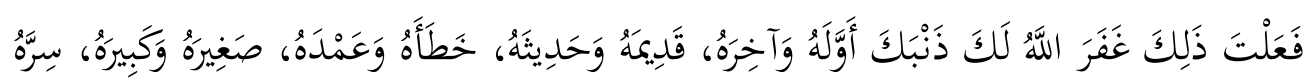

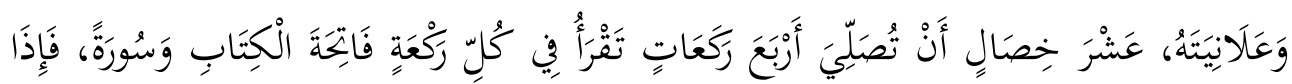

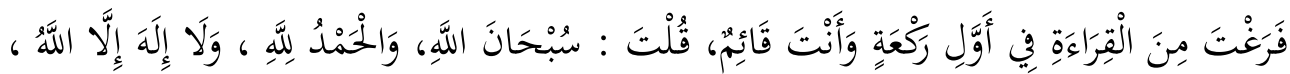

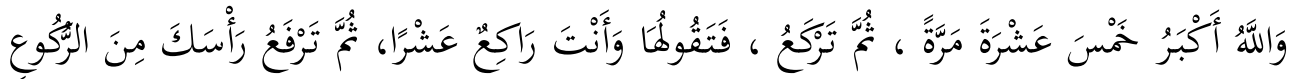

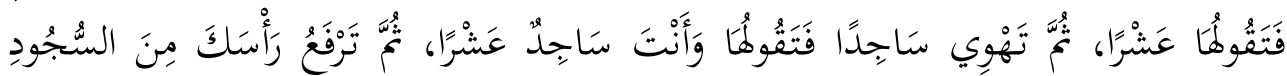

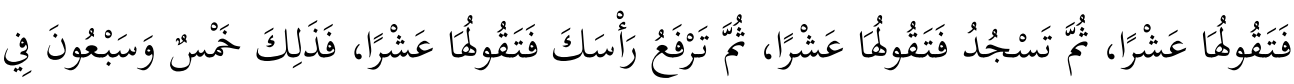

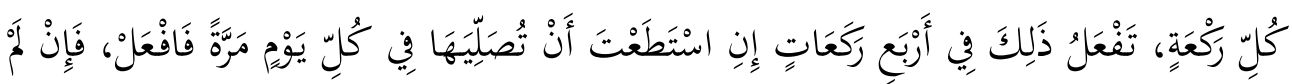

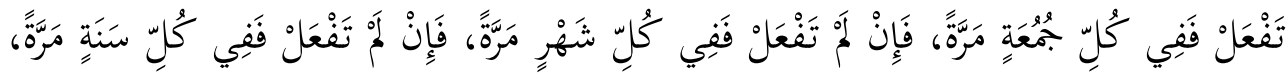

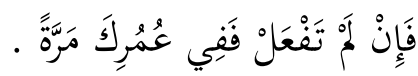

"Dari Ibnu 'Abbas, bahwa Rasulullah saw., berkata kepada al-'Abbas bin 'Abd alMuthalib. Kata beliau, "Hai pamanku, 'Abbas. Maukah Anda saya beri sesuatu? Maukah Anda saya anugrabi sesuatu? Maukah Andah saya badiahi sesuatu? Maukah Anda saya berbuat sesuatu? Ada sepuluh hal, apabila Anda melakukannya, maka Allah akan mengampuni dosa-dosa Anda. Dosa-dosa yang dulu maupun yang belakangan. Dosadosa yang lama maupun yang baru. Dosa-dosa yang tidak sengaja dilakukan maupun dosadosa yang sengaja dilakukan secara terang-terangan.

Sepulub hal, yaitu Anda salat empat rakaat. Setiap rakaat anda membaca surat alFatihah dan sebuah surah. Apabila Anda selesai membaca pada rakaat perrtama dan Anda masib berdiri, bacalah tasbih "Subhanallah wa al-hamdu li Allah wa la ilaha illa Allah wa Allah Akbar", sebanyak lima belas kali. Kemudian Anda ruku' dan bacalah tasbih tadi ketika Anda sedang ruku', sepulub kali. Kemudian Anda angkat kepala dari ruku', dan bacalah tasbib tadi sepulub kali. Selanjutnya Anda sujud, dan bacalah pada waktu sujud tasbih tadi sepulub kali. Kemudian Anda angkeat kepala Anda dari sujud, dan bacalah tasbib tadi sepulub kali.

${ }^{62}$ Lihat Ali Mustafa Yaqub, Hadis, h. 124. 
Kemudian Anda sujud lagi, dan bacalah tasbih sepulub kali. Kemudian Anda angkat kepala dan bacalah tasbih sepulub kali.

Make bacaan tasbih itu ada tujuh puluh lima untuk setiap rakaat. Anda kerjakan bal itu dalam empat rakaat. Apabila Anda mampu, kerjakanlah salat itu sekali dalam satu hari. Apabila Anda tidak mampu, kerjakan setiap Jum'at. Apabila Anda juga tidak mampu, maka kerjakanlab satu bulan satu kali. Apaabila Anda tidak mampu, maka kerjakan satu tabun satu kali. Dan Apabila Anda juga masib tidak mampu, kerjakanlah sekali dalam seumur bidup Anda. ${ }^{63}$

Hadis ini masuk dalam hadis palsu menurut Ibnu al-Jauz (w. 597 H), yang menurut Ali Mustafa Yaqub bahwa vonis hadis palsu tersebut terlalu terburu-buru, karena hanya mengambil dari riwayat Dar al-Qur'an melalui tiga jalur. ${ }^{64}$ Pertama, jalur yang terdapat nama Sadaq bin Yazd al-Khurasn yang menurut al-Bukhari sebagai munkar al-Yad, sanadnya terputus menurut Ibnu Hibban. Kedua, jalur yang terdapat nama Musa bin 'Abd al-'Aziz yang menurut al-Jauzi tersebut tidak diketahui (majhul). Ketiga, jalur yang terdapat nama Musa bin 'Ubaidah yang dinilai riwayatnya tidak halal diriwayatkan. ${ }^{65}$ Maka, banyak menganggap hadis tentang salat Tasbih palsu sesuai pendapat Ibnu al-Jauzi.

Menurut Ali Mustafa Yaqub, hadis ini bukan hanya diriwayatkan dari jalur Dar al-Qur'an saja. Tapi banyak ulama lain yang meriwayatkan hadis tersebut. Mengingat banyak jalur periwayat, maka al-Jauzi salah kalau langsung mudah memvonis hadis palsu. ${ }^{66}$ Pertama, kesalahan al-Jauzi mengenai jalur pertama yang ada nama cadaqah bin Yazid al-Kurasan, padahal nama yang ada disitu adalah sadaqah bin "Abd Allah ad-Dimasqi yang memang lemah hafalannya tapi, dinilai banyak ulama kredibel (fiqab). Kedua, jalur terdapat nama Musa bin 'Abd al-'Aziz yang dianggap tidak dikenal, padahal banyak kritukus hadis yang mengetahui nama tersebut dan dinilai kredibel (fiqab) seperti pendapat Ibnu ibbn dan al-Bukhariy yang meriwayatkan hadis darinya. ${ }^{67}$ Ketiga, jalur riwayat yang ada nama Musa bin 'Ubaid yang banyak ulama berpendapat bahwa ia memang lemah (da'if), tapi tidak menjadikan hadisnya palsu, bahkan Ibnu Sa'ad menilainya kredibel, serta hadis yang diriwayatkan dari imam yang lain bernilai shahih, juga hadis ini diamalkan oleh Imam al-Bukhariy dan Muslim dan banyak ulama lain seperti MM Azami, dan Nashur ad-Din al-Albaniy. ${ }^{68}$

c. Kalau Istiqamah Enggak Bakal Takut Enggak Bakal Sedih

\footnotetext{
${ }^{63}$ Lihat Ali Mustafa Yagub, Hadis, h. 125-126.

${ }^{64}$ Lihat Ali Mustafa Yaqub, Hadis, h. 127

${ }^{65}$ Lihat Ibnu al-Jauz ${ }^{3}$, Kitab, h. 63-65.

${ }^{66}$ Lihat Ali Mustafa Yagub, Hadis, h. 128

${ }^{67}$ Ibid., h. 129

68 Ibid., h. 130-131
} 
Buku tersebut adalah karya terakhir dari Ali Mustafa Yaqub sebelum beliau wafat. Sebenarnya Ali Mustafa Yaqub ingin menyajikan buku tersebut tetap ilmiah, tetapi dewan penerbit mengharap buku yang disajikan untuk kalangan masyarakat umum dengan bahasa informal, sehingga Ali Mustafa Yaqub setuju dengan pendapat ini. ${ }^{69}$ Ahmad Najib selaku penerbit mengungkapkan:

"Saat kami pertama kali bertemu, secara kbusus K.H. Ali Mustafa Yaqub menceritakan sebuah karya beliau yang ditulis Bahasa Arab, berjudul Al-Thuruq Al-Shabihah Fi Fahmi Al-Sunnah Al-Nabawiyah. Bagi beliau, buku tersebut sangat penting, sehingga buku yang seharusnya terdiri dari tiga bab itu segera beliau terbitkan ketika baru selesai satu bab. Alasannya, karena beliau khawatir keburu meninggal sebelum bisa mempublikasikan karya yang sangat penting dalam memahami hadis ini. Alhamdulillah akbirnya beliau bisa menyelesaikan karya tersebut secara sempurna. Bagaimanapun, seolah menguatkan firasat beliau, K.H. Ali Mustafa Yaqub meninggal 28 April 2016, sebulan sebelum buku diluncurkan pada acara wisuda Pesantren Darus Sunnab 28 Mei 2016."70

Buku inipun sudah bisa diakses melalui 'Google Book.' Dalam buku terakhir Ali Mustafa Yaqub ada mengangkat tema yang judulnya 'Tersenyum Sebelum Ajal' pada halaman 77 sampai 87. Tema tersebut mengisyaratkan bahwa, seolah-olah dalam kitab hadis terakhir ini beliau sudah tahu, bahwa akan sampai ajalnya. Ali Mustafa Yaqub memulai buku tersebut dengan mengutip hadis nabi yang berbunyi:

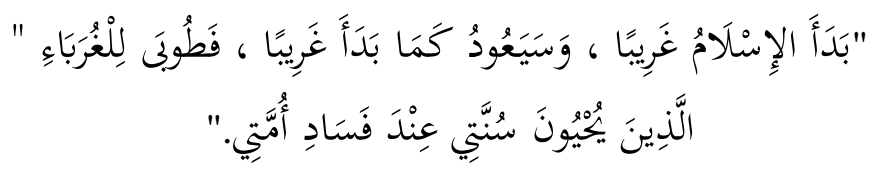

"Islam ini bermula sebagai sesuatu yang asing, yang tidak dikenal dan tidak mau dikenali oleh orang-orang dan akan kembali asing, tidak dikenal dan tidak man dikenal oleh orang-orang. Beruntunglab bagi mereka yang asing, yaitu orang-orang yang menghidupkan sunnabku ketika sunnabku sudah bancur." "11

Ali Mustafa Yaqub mengungkapkan kata pertanyaan "Bagaimana menghidupkan sunnahku? Disini beliau langsung memberikan jawaban. Pertama, amalan ibadah dan perlaku Rasulullah dijadikan sebagai anutan oleh umat Islam. Kedua, umat Islam ketika beribadah berdasarkan pada sunnah-sunnah Nabi saw.

${ }^{69}$ Lihat 'kata Pengantar' dari penerbit dalam Ali Mustała Yagub, Kalau, h. viii

${ }^{70}$ Lihat Ali Mustafa Yagub, Kalau, h. vii

${ }^{71}$ Ibid., h. 77 . 
Berpegang pada sunnah Nabi saw., ini sudah dianggap aneh atau sudah tabu bagi umat Islam sendiri saat ini. Alasan ini didapat berdasarkan pengalaman beliau disaat mengajar di IAIN Syarif Hidayatullah 1996 yang menjelaskan hadis tentang; "siapa yang mencari ilmu syar'i, ilmu agama untuk membanggakan diri pada orang bodoh, untuk mendebat ulama, dan untuk mencari harta dunia, maka Allah mengharamkan orang tersebut masuk surga", justru dianggap mahasiswa hal tersebut kolot dan kuno dan bukan bentuk dari kemodernan dan berfikir kritis. $^{72}$

Pernah beliau menjadi pembicara saat seminar 'Arah Kiblat'. Beliau melihat bahwa, Ilmu Falaq tidak lagi menjadi kajian yang mengasikkan dan digandrungi umat Islam ketika beliau menjelaskan arah kiblat. Mereka lebih berkiblat pada 'Google Map' dibandingkan dalil syar'i berdasarkan Alquran, hadis, ijma' dan qiyas sikap tersebut merupakan gambaran bahwa umat Islam kembali lagi ke zaman jahiliah modern. Ilmu Atronomi memang sains, tapi bukan merupakan dalil syari’ sebagaimana bukanlah 'Google Map' sebagai dalil syar'i. Padahal, untuk ibadah harus senantiasa menggunakan dalil syar'i. Beliau berkata: "Saya lebih senang digebukin anda saat ini, dari pada digebukin malaikat dipintu neraka karena meninggalkan hadis dalam beribadah."73

Kemudian, beliau menjelaskan fenomena masyarakat yang lebih senang dengan umroh daripada membantu orang, mereka lebih berfikir tentang rekening dunia daripada rekening akhirat, orang seperti ini pasti takut menghadapi kematian. Sebaliknya, bila orang itu baik yang selalu mengumpulkan rekening akhirat, maka ia tidak takut menghadapi kematian bahkan lebih rindu dan senang akan akhirat. Pemikiran seperti ini sudah sangat tabu dan sudah jarang pada umat Islam dewasa ini, ungkap Ali Mustafa Yaqub dengan mengutip hadis yang berbunyi: ${ }^{74}$

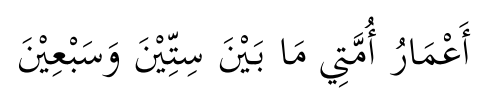

"Umur umatku itu antara 60 sampai 70 tabun."

Karena umur terbatas, pesan Ali Mustafa Yakub kemudian adalah bila punya ilmu atau uang, maka gunakan itu untuk berinfaq sebanyak-banyaknya dan itu sunnah Rasulullah sebagai rekening akhirat, kalau tidak ada baca tasbih sebanyak-banyaknya, yang itu lebih mudah. Kalau keduanya tidak mau, maka ketika malaikat maut datang, hanya bisa menangis dan ketakutan yang amat

72 Ibid., h. 78.

${ }^{73}$ Lihat Ali Mustafa Yagub, Kalau, h. 78-79

${ }^{74}$ Ibid., h. 81-86. 
sangat. Ali Mustafa Yakub mengakhiri bab tersebut dengan kata: ${ }^{75}$ "Kalau calon pengbuni sorga, dia akan tersenyum menyambut kematian."

\section{Refleksi Pemikiran Ali Mustafa Yaqub}

Ali Mustafa Yaqub sebagaimana adalah ulama hadis di Indonesia yang hidupnya hanya belajar, mengajar dan mengajak umat Islam untuk senantiasa berpegang pada hadis nabi. Kehidupan yang mulai dari kecil hingga sekolah, selalu dalam kajian Agama Islam membentuk pemahaman yang utuh tentang Islam itu sendiri. Hadis merupakan sumber kedua sesudah Alquran pun menjadi pedomannya bagaimana hidup seperti Rasul.

Pemikirannya yang tegas dan berkarakter menggambarkan orisinalitas pemahamannya terhadap hadis. Beliau orang yang toleran, tapi peduli dengan permasalahan-permasalahan umat di Indonesia. Hal itu tercermin dari karyanya yang selalu berlatar kejadian yang ada. Kejadian ini menjadi PR baginya untuk dianalisa dalam perspektif Alquran dan hadis dari berbagai macam 'pisau bedah' analisa.

Hadis dan ilmu hadis merupakan senjata beliau dalam menghadapi pemikiran-pemikiran yang sesat, sempit, dan radikal. Berbekal hadis sebagai ilmunya pun sudah cukup menghiasi khasanah keilmuan dalam kajian sunnah Nabi. Conter pemikiran Barat pun beliau lakukan untuk membela sunnah. Agar pemikiran yang sesat dan menyesatkan tidak berefek terhadap pemahaman hadis masyarakat Indonesia. Lewat bukunya itu, terlihat bahwa beliau cinta Allah, Rasulnya, Islamnya, dan cinta rakyat Indonesia.

Inspirasi pemikiran beliau, sebagai batu loncatan yang besar bagi perkembanagan kajian hadis di Indonesia khususnya. Beliau sudah mendudukkan kajian hadis sebagaimana mestinya tanpa mendikotomikan ilmu lain seperti Alquran, tafsir, fiqih dan usul fiqih, sejarah sebagai jalan untuk mamahami dan mengkaji sunnah Nabi yang merupakan salah satu pedoman syariat bagi umat Islam di Indonesia.

Terakhir, disamping beliau meninggalkan karya-karyanya, beliaupun mewariskan sistem untuk memahami hadis Nabi saw., lewat Pondok Pesantren Darussunah yang beliau dirikan di Jakarta. Sistem tersebut nantinya akan menjadi mesin produksi yang akan melahirkan ahli-ahli hadis yang kredibel, serta berani membela Islam dan muslim. Mencerdaskan umat Islam, bukan hanya di Indonesia tapi dunia, sebagai jalan awal kebangkitan Islam dan Muslimin.

${ }^{75}$ Lihat Ali Mustafa Yagub, Kalau, h. 87. 
Selalu ada ruang kosong yang tetap dapat dikaji dalam pemikiran beliau, seperti orisinalitas dan otentisitas hadis yang beliau nukilkan dalam kitabnya, pensyarahan terhadap pemikiran hadis beliau, serta fiqhi hadis yang mulai marak kajiannya di Indonesia. Ruang kosong ini menjadi penelitian yang lebih dalam dan kredibel, agar menjadi pencerah dan penggerak pemikiran pada zamannya. Pensyarahan hadis, dan fiqhi hadis ini merupakan metode untuk menyelesaikan permasalahan-permasalahn umat yang nantinya akan lebih berkembang semakin pelik dan lebih komplek lagi seoring dengan kemajuan zaman yang semakin berkembang dan semakin maju.

\section{Kesimpulan}

Dari pemaparan di atas, dapat diambil kesimpulan bahwa menurut Ali Mustafa Yaqub, keaslian hadits dapat diketahui dengan membandingkan dengan hadits lain, baik dari teman, dari segi waktu maupun waktu, dari berbagai perawi, maupun guru atau karya dalam sebuah kitab hadits, sehingga kredibilitas hadits tersebut dikenal. Adapun kontribusinya terhadap pemikiran hadits yaitu mengenalkan pemikiran orientalis dan membela ulama, kemudian mengembangkan metode pemahaman hadits dengan mendirikan Pondok Pesantren Darussunnah, menulis berbagai pemikiran hadits yang mengandung rekonstruksi ulang pemahaman terhadap hadits baik dalam bentuk kritik, atau pemikiran baru tentang hadits seperti makna bid'ah atau hadits dalam perdebatan masyarakat terkait hukum

Ali Mustafa Yaqub dengan memberi apresiasi yang mendalam tentang, perjalanan hidup, karya-karya, serta mimpi beliau akan berjalannya sunnah Nabi di bumi Indonesia. Beliau cukup besar perannya sebagai inspirator terhadap kajian, dan pemahaman hadis. Wacana-wacana tentang pemikiran hadis dan mempertahankan sunnah dari serangan Barat yang beliau buktikan kepada masyarakat Indonesia. Beliau tinggalkan warisan berupa energy, pemikiran dan sistem untuk menapaki jejak kenabian untuk kajian keilmuan hadis sesudahnya.

\section{Biblografi}

Ali Mustafa Yaqub. At-Turuq as-Sabihah Fi Fabm as-Sunnab an-Nabawiyyah. Jakarta: Maktabah Darus-Sunnah, 2016.

- Fatwa-Fatwa Imam Besar Masjid Istiqlal (Jakarta: , 2008), h. Jakarta: Pustaka Firdaus, 2008.

. Haji Pengabdi Setan. Jakarta: Pustaka Firdaus, 2006.

. Islam Masa Kini. Jakarta: Pustaka Firdaus, 2006.

. Kalau Istiqamah Enggak Bakal Takut Enggak Bakal Sedih. Jakarta: Naora, 2016.

- Kerukunan Umat Perspektif Al-Quran Dan Hadis. Jakarta: Penerbit Pustaka Firdaus, 2008. 
. Peran Ilmu Hadis Dalam Pembinaan Hukum Islam. Jakarta: Pustaka Firdaus, 1999.

- Sejarah Metode Dakwah Nabi (Jakarta: Pustaka Firdaus, 2003), h. 155. Jakarta: Pustaka Firdaus, 2003.

- Toleransi Antar Umat Beragama. Jakarta: Penerbit Pustaka Firdaus, 2008.

"Ali Mustafa Yaqub Pesan Makam 2 Tahun Sebelum Wafat - News Liputan6.Com." Accessed November 3, 2020. https://www.liputan6.com/news/read/2494833/ali-mustafa-yaqubpesan-makam-2-tahun-sebelum-wafat.

Ali Wafa. "Manhaj Asy-Syaikh "Ali Mustafa Yaqub Fi Fahm al-Ahya anNabawiyah." Skripsi, UIN Syarif Hidayatullah Fak. Dirasat Islamiyah, 2014.

AM. Waskito. KH. Ali Mustafa Yaqub: Menjaga Sunnah Mengawal Akidah. Jakarta: Pustaka al-Kautsar, 2016.

Anggraeni, Dewi, and Siti Suhartinah. "Toleransi Antar Umat Beragama

Perspektif KH. Ali Mustafa Yaqub.” Jurnal Studi Al-Qur'an 14, no. 1 (January 1, 2018): 59-77. doi:10.21009/JSQ.014.1.05.

Arwin Juli Rahmadi Butar Butar. Mengenal Karya-Karya Ilmu Falak Nusantara: Transmisi, Anotasi Dan Biografi. Yogyakarta: LKiS, 2017.

Ayung Darun Setiadi. Pendidikan Pesantren," Dalam Buku Ilmu \& Aplikasi Pendidikan. Bandung: PT. Imperial Bhakti Utama, 2007.

Cholidi Ibhar. Mengais Keteladanan Dari Kiai Syansuri Badawi. Jombang: Pustaka Tebuireng, 2017.

Fathurrahman Karyadi. Tokoh Besar Dibalik Layar: Biografi Almarbum KH. Idris Kamali. Jombang: Pustaka Tebuireng, 2010.

George A. Makdisi. Cita Humanisme Islam, Terj. A. Syamsu Riz̧al \& Nur Hidayah. Jakarta: Serambi, 2005.

Hartono. "Perkembangan Pemikiran Hadis Kontemporer Di Indonesia: Studi Atas Pemikiran Abdul Hakim Abdat Dan Ali Mustafa Yaqub." Tesis, Sekolah Pascasarjana UIN Syarif Hidayatullah, 2009.

Hasanah, Annisa Nurul. "Mengenal K.H. Ali Mustafa Yaqub: Ahli Hadis Indonesia Abad ke-21 - Bincang Syariah.” BincangSyariah | Portal Islam Rahmatan lil Alamin, July 16, 2018. https://bincangsyariah.com/khazanah/mengenal-k-h-ali-mustafayaqub-ahli-hadis-indonesia-abad-21/.

Isnaeni, Ahmad. "Historitas Hadis Dalam Kacamata M. Mustafa Azami." Epistemé: Jurnal Pengembangan Ilmu Keislaman 9, no. 2 (December 10, 2014): 233-48. doi:10.21274/epis.2014.9.2.233-248.

Istianah, Istianah. "Kontribusi Ali Mustafa Yaqub (1952-2016) Dalam Dinamika Kajian Hadis Di Indonesia." Riwayah 3, no. 1 (2017): 11-22. doi:10.21043/riwayah.v3i1.3442. 
Jamal Ma'mur Asmani. Mereguk Kearifan Para Kiai. Jakarta: Gramedia, 2018.

Khairul Imam Ghozali. "Tangis Haru Ratusan Santri Antar Jenazah KH Ali Mustafa Yaqub Ke Pemakaman.” Accessed November 3, 2020. https:// news.detik.com/berita/d-3198865/tangis-haru-ratusan-santriantar-jenazah-kh-ali-mustafa-yaqub-ke-pemakaman.

M, MISKI M. "Pemahaman Hadis Ali Mustafa Yaqub Studi Atas Fatwa Pengharaman Serban Dalam Konteks Indonesia.” Accessed November 3, 2020. doi:10.21043/riwayah.v2i1.1625.

Muhammad Al-Fitra Haqiqi. 50 Ulama Agung Nusantara Jombang: Darul Hikmah, 2009), b. 113-118. Jombang: Darul Hikmah, 2009.

Muhammad Koderi. Bolehkah W anita Menjadi Imam Negara. Jakarta: Gema Insani Press, 1999.

Mujamil Qomar. Pesantren: Dari Transformasi Metodologi Menuju Demokeratisasi Institusi. Jakarta: Penerbit Erlangga, 2010.

Mulyadi Kartanegara. Integrasi Ilmu: Sebuah Rekonstruksi Holistik (Jakarta: , 2005), b. 215-216. Jakarta: Arasy Mizan, 2005.

Ni'ma Diana Kholidah. "Kontribusi Ali Mustafa Yaqub Terhadap Kajian Hadis Kontemporer Di Indonesia,” Skripsi.” UIN Syarif Hidayatullah, 2011.

Nurdin, Nasrullah. "Prof. Dr. KH. Ali Mustafa Yaqub, MA.: Muhaddis Nusantara Bertaraf Internasional.” Jurnal Lektur Keagamaan 14 (June 30, 2016): 197. doi:10.31291/jlk.v14i1.481.

Ramadhan. "Metode Kritik Hadis Ali Mustafa Yaqub; Antara Teori Dan Aplikasi." Accessed November 3, 2020. http://journal.tebuireng.ac.id/index.php/nabawi/article/view/5.

Ramli Abdul Wahid. Sejarah Pengkeajian Hadis Di Indonesia. Medan: IAIN Press, 2010.

Rofiq, Mohammad. "Etika Dakwah: Menyikapi Fenomena Da’i Bertarif." MIY AH: Jurnal Studi Islam 11, no. 2 (February 25, 2017): 239-58.

Rohmansyah, Rohmansyah. "Hadith Hermeneutic of Ali Mustafa Yaqub." KALAM 11, no. 1 (June 30, 2017): 187-214. doi:10.24042/klm.v11i1.1053.

Yaqub, Ali Mustafa. "Autentisitas Dan Otoritas Hadis Dalam Khazanah Keilmuan Ulama Muslim Dan Sarjana Barat." Tarjih: Jurnal Tarjih dan Pengembangan Pemikiran Islam 7, no. 1 (2004): 33-41.

Yogi Sulaeman. "Analisis Wacana Kritis 'Dai Komersial' Dalam Buku Setan Berkalung Surban Karya Prof. Dr. KH. Ali Mustafa Yaqub, MA." Skripsi, UIN Syarif Hidayatullah Fak. Dakwah dan Komunikasi, 2015. 